\title{
English Language Competence of Future Engineers: From Federal State Educational Standard to Tomsk Polytechnic University Best Practices
}

\author{
Lyubov N. Goryanova
}

PhD in Philology, Department of Methods of Teaching Foreign Languages, Institute of Strategic Partnership and Competences Development, National Research Tomsk Polytechnic University, Tomsk, Russia

Email: rollingdown@mail.ru

\section{Darya S. Denchuk}

PhD Student in Pedagogy, Department of Engineering Pedagogy, Institute of Strategic Partnership and Competences Development, National Research Tomsk Polytechnic University, Tomsk, Russia

Email: eds@tpu.ru

\section{Doi:10.5901/mjss.2015.v6n3s1p290}

\section{Abstract}

Engineering education is one of Russia's priority development areas allowing the country to increase the competitive capacity of its economy in the present world by establishing an effective segment of the national innovative system. Russian national research technical universities are regarded as a powerful force to train highly professional engineering specialists. An essential part of future engineer's professionalism is foreign language proficiency, particularly proficiency in English as the language of international importance. A range of language skills that students should acquire through mastering a basic educational programme within the chosen direction of training will help them fully realise their potential and become competitive at the international level. In this article, the requirements for bachelor engineers' foreign language competences determined by the Federal State Educational Standard of Higher Professional Education (FSES HPE) in Russia are analysed for their correspondence to the country's and global demands that are currently challenging professional engineers. The research procedure and the principles of selecting directions of engineering training for the present analysis are provided, the obtained results are presented and the corresponding conclusions are made. Further, National Research Tomsk Polytechnic University (TPU) best practices of priority engineering training are described. It is believed that the university's experience can be successfully adopted by other Russian institutions of higher professional education aimed at training professional engineers for the benefit of the country.

Keywords: professional engineering education, foreign language competence, English language proficiency of engineering specialists, Federal State Educational Standard of Higher Professional Education, Tomsk Polytechnic University.

\section{Introduction}

In Russia, the system of higher professional education is exercised in compliance with FSES HPE. The standard sets particular requirements for the mandatory minimum of universities' basic educational programmes (BEPs), the conditions of BEP implementation, the time period sufficient for BEP completion, and the maximum hours of academic workload for students. Thus, FSES HPE is a basis for shaping and supporting the unified educational space in the country.

Until 2009, there were two generations of FSES HPE. Both standards were based on the concept of knowledge, skills and abilities development. The three aspects were regarded as the key ones forming the professional qualification of a future specialist. In 2009, in accordance with the Russian Federation legislation, training of future specialists in the system of higher professional education became two-level with 4 years for mastering a bachelor's programme and 2 years for completing a master's programme. Since then, the system of education at universities has been defined by FSES of the 3rd generation focused on a competence-based approach to BEP implementation and mastering.

According to the competence model of the 3rd generation FSES HPE, under completion of BEP for each degree in the chosen direction of training, a student should possess a number of competences comprising two basic groups: universal and professional. The list of competences that should be gained was identified for each particular direction of training according to the demands of the international world. However, despite the fact that FSES HPE list of universal and professional competences is quite large for each direction of training for both a bachelor's and master's degree, 
practice shows that not all competences fully satisfy the new challenges of the present world of global competitiveness. Consequently, the leading universities in Russia have been allowed to develop their own BEPs with the purpose to deepen FSES requirements for specialists' competences and address the current demands for future professionals' skills at a national and international level.

At the present state of Russian economic development and transition to a new level of industrialisation, the priority in the country is given to innovative development as an essential part of global competitiveness. Engineering education is regarded as one of the key factors allowing the country to move from resource-based economy to that of high technology and innovation. In this situation, the modern system of engineering education should be ready to respond to the increasing need for highly qualified specialists who could solve the new tasks and meet the new challenges. Thus, in the National Doctrine on Education in the Russian Federation for 2025, one of the priorities is aimed at training highly qualified specialists able to take the initiative in their professional advancement and mobility in the age of society informatisation and high technology development (The Order of the Russian Federation Government of October 4, 2000).

One of the competences that a modern engineer should possess is related to a foreign language proficiency. Obviously, the priority is given to English as the language of international significance. Indeed, communicating in English at a professional level is crucial for any highly professional engineer who wishes to be successful and competitive in his career. However, a vast majority of engineers in Russia experience a lot of challenges in using English as a foreign language for professional purposes. Therefore, being skilled and knowledgeable in particular directions of engineering, young specialists are unable to work abroad, collaborate with foreign partners, participate in international conferences and publish in scientific journals in order to present their innovative projects and developments to the international community.

The present paper aims to identify to what extent the expected foreign language competences and learning outcomes established by the $3^{\text {rd }}$ generation FSES HPE for engineering specialists correlate with the current challenges of a national and international character. The found gap between the requirements set by FSES HPE and the reality can be effectively filled by pursuing special university policy of training engineers of a new generation. Thus, sharing TPU best practices in this respect is within the scope of this article as well.

\section{Methodology}

On July 7, 2011, the Executive Order «On Approving Priority Development Areas in Science, Technology and Engineering in the Russian Federation and the List of Critical Technologies in the Russian Federation» was signed. The approved list of development priorities in science, technology and engineering was aimed at promoting modernisation and technological development of the Russian economy and improving its competitiveness (Development Priorities in Science, Technology and Engineering in the Russian Federation Have Been Approved // President of Russia). The following areas were identified as the priority ones: security and counter-terrorism; nanosystems; information and telecommunications systems; life sciences; advanced weapons, military and special technology; environmental management; transport and space systems; energy efficiency, energy saving, nuclear power. Since then, following the established areas, Russian national research technical universities, which are regarded as a powerful force for the country's economic development in advanced technologies and innovation, have been providing educational programmes for students to obtain their bachelor's and master's degree in the chosen specialities.

To perform the present research, various directions of engineering training were chosen form FSES HPE of the $3^{\text {rd }}$ generation. The focus was on the directions for a bachelor's degree only as precisely in this period of 4-year training the major competences and skills required for a future specialist's professional realisation are formed. Two overall criteria were set for the selection process. First, correspondence of those directions to the Russian priority development fields in science, technology and engineering; second, availability of such training at TPU. In total, the following 17 standards of priority directions of training were chosen:

1. Information Systems and Technologies.

2. Informatics and Computer Engineering.

3. Software Engineering.

4. Electronics and Nanoelectronics.

5. Instrument Engineering.

6. Optical Engineering.

7. Bioengineering Systems and Technologies.

8. Heat and Power Engineering and Heat Engineering.

9. Electrical Power Engineering and Electrical Engineering. 
10. Power Machinery Engineering.

11. Nuclear Physics and Technologies.

12. Workflow and Production Automation.

13. Mechatronics and Robotics.

14. Chemical Engineering.

15. Energy-Efficient and Resource Saving Processes in Chemical Technology, Petrochemistry and Biotechnology.

16. Biotechnology.

17. Materials Science and Technologies.

Each of the selected direction of priority engineering training was analysed for two FSES HPE requirements in terms of foreign languages. The first requirement concerned the expected foreign language competence for future engineers to gain. The second one focused on the expected learning outcomes. The obtained results were summarised in the table below.

Table 1. FSES HPE Foreign Language Competences and Learning Outcomes for Students to Obtain in Bachelor's Directions of Engineering Training under Analysis.

\begin{tabular}{|c|c|c|c|}
\hline № & Direction of Training & Foreign Language Competence & Learning Outcomes \\
\hline 1. & Information Systems and Technologies. & $\begin{array}{l}\text { Being proficient in a foreign language at } \\
\text { a sufficient level. }\end{array}$ & $\begin{array}{l}\text { Knowing a minimum of } 4000 \text { words of general } \\
\text { and professional orientation in a foreign } \\
\text { language. } \\
\text { Being able to use foreign language resources } \\
\text { to obtain the necessary information. }\end{array}$ \\
\hline 2. & Electronics and Nanoelectronics. & \multirow{4}{*}{$\begin{array}{l}\text { Being proficient in a foreign language at } \\
\text { the level equal or higher than } \\
\text { conversational. }\end{array}$} & \multirow{4}{*}{$\begin{array}{l}\text { Knowing a minimum of } 4000 \text { words of general } \\
\text { and professional orientation in a foreign } \\
\text { language. } \\
\text { Being able to use foreign language resources } \\
\text { to obtain the necessary information. }\end{array}$} \\
\hline 3. & $\begin{array}{l}\text { Bioengineering Systems and } \\
\text { Technologies. }\end{array}$ & & \\
\hline 4. & Mechatronics and Robotics. & & \\
\hline 5. & Materials Science and Technologies. & & \\
\hline 6. & Informatics and Computer Engineering. & $\begin{array}{l}\text { Being proficient in a foreign language at } \\
\text { the level equal or higher than } \\
\text { conversational. }\end{array}$ & $\begin{array}{l}\text { Being able to use a foreign language in } \\
\text { professional and interpersonal } \\
\text { communication. }\end{array}$ \\
\hline 7. & Instrument Engineering. & \multirow{2}{*}{$\begin{array}{l}\text { Being able to use a foreign language in } \\
\text { communication and professional } \\
\text { activity at the level equal or higher than } \\
\text { conversational. }\end{array}$} & \multirow{2}{*}{$\begin{array}{l}\text { Being able to translate texts of general and } \\
\text { professional orientation in a foreign language. } \\
\text { Knowing a minimum of words of professional } \\
\text { orientation in a foreign language. }\end{array}$} \\
\hline 8. & Optical Engineering. & & \\
\hline 9. & $\begin{array}{l}\text { Heat and Power Engineering and Heat } \\
\text { Engineering. }\end{array}$ & \multirow[t]{3}{*}{ Being able to use a foreign language. } & \multirow{3}{*}{$\begin{array}{l}\text { Knowing a minimum of words of general and } \\
\text { professional orientation in a foreign language. } \\
\text { Being able to use foreign language resources } \\
\text { to obtain the necessary information. }\end{array}$} \\
\hline 10. & $\begin{array}{l}\text { Electrical Power Engineering and } \\
\text { Electrical Engineering. }\end{array}$ & & \\
\hline 11. & Power Machinery Engineering. & & \\
\hline 12. & Nuclear Physics and Technologies. & \multirow{2}{*}{$\begin{array}{l}\text { Being proficient in a foreign language at } \\
\text { the level equal or higher than } \\
\text { conversational. }\end{array}$} & \multirow{2}{*}{$\begin{array}{l}\text { Being able to use foreign language resources } \\
\text { to obtain the necessary information. }\end{array}$} \\
\hline 13. & Workflow and Production Automation. & & \\
\hline 14. & Chemical Engineering. & \multirow{3}{*}{$\begin{array}{l}\text { Being proficient in a foreign language at } \\
\text { the level equal or higher than } \\
\text { conversational. }\end{array}$} & \multirow{3}{*}{$\begin{array}{l}\text { Knowing a minimum of } 4000 \text { words of general } \\
\text { and professional orientation in a foreign } \\
\text { language. }\end{array}$} \\
\hline 15. & $\begin{array}{l}\text { Energy-Efficient and Resource Saving } \\
\text { Processes in Chemical Technology, } \\
\text { Petrochemistry and Biotechnology. }\end{array}$ & & \\
\hline 16. & Biotechnology. & & \\
\hline 17. & Software Engineering. & $\begin{array}{l}\text { Being proficient in a foreign language at } \\
\text { the level equal or higher than } \\
\text { conversational. }\end{array}$ & $\begin{array}{l}\text { Knowing a minimum of } 4000 \text { words of general } \\
\text { and professional orientation in a foreign } \\
\text { language. } \\
\text { Being able to use a foreign language in } \\
\text { professional and interpersonal } \\
\text { communication. } \\
\text { Being able to use foreign language resources } \\
\text { to obtain the necessary information. }\end{array}$ \\
\hline
\end{tabular}


As seen from Table 1, some directions have equal requirements for foreign language competences and learning outcomes. For this reason, they were combined in mini groups.

\section{Results and Discussion}

The analysis showed that the foreign language competences refer to the group of universal competences in all the selected directions of engineering training. In other words, language proficiency is regarded as part of future engineer's professional background in terms of their ability to communicate in this language. However, the exact level of foreign language proficiency is unclear. It is defined as sufficient, and equal or higher than conversational. As can be seen in Table 1, for some directions, the reference is made to professional communication, though still on a conversational level. Thus, despite the fact that the emphasis is certainly put on communication skills that an engineering specialist should possess under graduation, there stays ambiguity about how to define to what extent professional those skills are. Consequently, the level of foreign language proficiency needs to be either clarified or marked according to the Common European Framework of References for Languages (Council of Europe, 2001).

Foreign language learning outcomes are set for each direction of training. Nevertheless, they are not detailed enough. For most directions, the obtained results refer to particular vocabulary that students should learn. It is specified as a minimum of words of general and professional orientation. In some cases, a definite number of 4000 words is provided. It should be mentioned that this number appears the only opportunity to approximately identify the expected level of language proficiency that students should gain - traditionally, 4000 words correspond to B2 or Upperintermediate. Despite this, the idea should be clearly expressed to avoid ambiguity.

For a number of directions, particular skills are outlined, such as being able to use foreign language resources to obtain the necessary information and being able to translate general- and professional-oriented texts in a foreign language. However, in the present world, a highly professional engineering specialist should possess a range of foreign language skills, including skills of presenting in a foreign language, writing for academic study, writing for scientific research, etc. Consequently, there should be a larger enumeration of specific learning outcomes for each direction of training in the list.

Thus, the undertaken analysis showed that FSES HPE competences and learning outcomes for the selected directions of engineering training provide a clear understanding that, as high professionals, engineers should demonstrate a good level of English language proficiency when communicating for professional purposes. However, neither the competences nor targeted results are thoroughly elaborated on. It my be concluded that FSES HPE requirements for educational programmes in the regarded directions do not reflect all the demands and challenges that young specialists will have to face in global workplace in terms of their proficiency in a foreign language, namely English as the language of international communication.

\section{TPU Best Practices}

The strategic goal of TPU, which is one of 15 best universities in Russia, is to become one of the world-leading research universities in the area of resource-efficient technologies solving global societal, economic and environmental problems for the benefit of the mankind sustainable development (Chubik et al., 2013). To achieve this goal, the university has developed an ambitious and forward-looking plan for 2013-2020 described in the Strategic Programme of National Research Tomsk Polytechnic University Competitiveness Enhancement in the Group of Top Level World Research and Academic Institutions. Thus, the entire policy of the university is aimed at realising the measures of its Strategic plan of development.

In accordance with its strategic goal and the country's priorities in engineering education, TPU aims to train highly professional competitive engineers able to fully realise their potential facing the new challenges of the international world. In 2012, the university developed its BEP Standard which defines Bachelors', Masters' and Specialists' Training in University's Priority Development Fields. The development and implementation of this Standard are based on a complex approach involving FSES requirements and criteria of public professional accreditation of programmes via Association for Engineering Education of Russia (AEER) - corresponding to international standards - Engineers Mobility Forum (EMF), APEC Engineer Register, Federation Europeenne d'Associations Nationales d'Ingenieurs (FEANI), Conceive - Design - Implement - Operate (CDIO), Conference of European Schools for Advanced Engineering Education and Research (CESAER), etc. (Educational Standard // TPU). Consequently, the requirements for the university's BEP Standard development are defined by the entire set of skills and competences that are currently associated with engineering specialists capable of building their professional career in the challenging world of global 
competitiveness.

In compliance with the new Standard, TPU has developed a special system of acquiring engineering educational programmes when students with different levels of initial knowledge and capabilities may select their own trajectory and obtain the targeted qualification. Three trajectories are offered.

1. Basic trajectory of BEP acquiring for students with good initial natural-scientific and mathematical background and average required skills.

2. Elite trajectory of BEP acquiring for talented students with high initial natural-scientific and mathematical background and the required skills at the level higher than average.

3. Adaptive trajectory of BEP acquiring for students with initial natural-scientific and mathematical background and the required skills lower than average.

The described division aims to create a student-centered educational environment and, consequently, train highly qualified specialists in the priority fields of science, technology and engineering. At the same time, such division allows selecting talented students and educate them within the elite trajectory of training helping them to become specialists of a new generation who will be capable of conducting complex scientific research, generating innovative ideas and producing competitive technologies for the benefit of the country's economy.

Regardless of the chosen educational trajectory, an essential role in studying is given to developing students' English language competence. Thus, the basic and adaptive trajectories imply learning general English for the first 4 semesters ( $256 \mathrm{~h}$. of classroom activities). Starting from the $5^{\text {th }}$ semester utill the end of studying within the programme, English is delivered for professional purposes (5-8 semesters, $129 \mathrm{~h}$. of classroom activities). Under completion of 4 years of studying for a bachelor's degree in a particular speciality, students should be able to demonstrate their English proficiency by using the language in all types of professional situations.

A foreign language competence that students should obtain under BEP mastering is specified as having the level of language proficiency sufficient for working in a foreign language environment, elaborating documentation, presenting and defending the results of innovative engineering activity. This competence fully complies with the requirements of the major international standards. The targeted level of English language proficiency is B2 or Upper-intermediate on the Common European Framework of Reference.

English is delivered within a compulsory discipline «Foreign Language». In addition to it, «Foreign Language for Academic Mobility» is offered to students in the group of optional disciplines. The course aims to equip learners with the necessary academic English skills which will be crucial in case they study abroad.

Students of the elite trajectory of BEP acquiring are taught within deep study of English. Such approach is regarded as an essential part of professional training of new generation engineers allowing them to actively participate in the programmes of international exchanges and internships and use English for their research. In addition, students have the opportunity to acquire part of their educational programme at TPU international partner universities. To broaden their perspective, students may do parallel study for concurrent diploma in modern languages as well.

In compliance with TPU BEP Standard-2012, the educational process at the university implies conference weeks. The purpose of such events is to provide students with the opportunity to demonstrate the achieved learning outcomes and acquire the experience of professional communication in Russian and foreign languages. In terms of English, this is an opportunity for students to practice using the language and become proficient, persuasive and effective in professional communication within the chosen speciality through delivering presentations, taking part in dialogues, discussions, etc.

As has been mentioned, the principles of training future engineers in the sphere of English language use are defined by the Strategic Programme of the university's development. A key part of TPU Strategic plan is to develop a dual linguistic academic and social environment with Russian and English as two equal components (Chubik et al., 2013). Increasing the number of programmes delivered in English and certified by international accreditation agencies is one of the ways to realise this ambition. At present, more than 40 TPU BEPs (more than 23\% of the total number of programmes) have received positive assessment and recognition in the Accreditation Board for Engineering and Technology (ABET), Canadian Engineering Accreditation Board (CEAB) and Association for Engineering Education of Russia (AEER) with the subsequent award of the EUR-ACE Label. Furthermore, TPU is the first university in Russia to join the Worldwide CDIO Initiative which aims to strengthen practical orientation of technical education and introduction of the system of problem-oriented and project-oriented training (CDIO Initiative // TPU). An essential aspect of this approach is to enable future engineers to gain proficiency in English for professional purposes. Thus, still studying at the university, engineering students should already be able to demonstrate their English language skills at various levels - from communicating in English to writing scientific research articles for publication in international journals. 


\section{Conclusion}

FSES HPE requirements for foreign language competences and learning outcomes that engineering students should gain under graduation with a bachelor's degree are insufficient in terms of international standards of engineering education and the world's challenges for future engineers to meet. In the present world, a professional engineer should be able to communicate in English at a professional level. B2 or Upper-intermediate on the Common European Framework of Reference can be regarded as the targeted proficiency level to gain at a university as such level is sufficient to use the language fluently, without extra help or support. In addition, engineers should be able to collaborate with foreign partners and present their innovative projects to the international community by participating in scientific conferences and other research events and publishing in English in international journals. Thus, FSES HPE foreign languages competences and learning outcomes should be reconsidered in order to comply with the current national and global demands for engineering specialists.

To address the current challenges and train high professionals, TPU is actively developing an innovative approach to engineering education. Following the requirements and recommendations of a number of professional international accreditation agencies, the university focuses on the outcome-based approach to its educational process. This approach is aimed at developing a range of essential skills which will enable future specialists to effectively undertake their professional activity through the medium of English. Thus, English language learning is among TPU first priorities. The university's experience described in this paper can be successfully adopted by other Russian universities which aim to train professional engineers for the benefit of the country as well.

\section{Acknowledgement}

This work was funded within the framework of realisation of Strategic Programme on National Research Tomsk Polytechnic University Competitiveness Enhancement in the Group of Top Level World Research and Academic Institutions.

\section{References}

CDIO Initiative // National Research Tomsk Polytechnic University. [Online] Available: http://tpu.ru/en/academics/ao/cdio/ (March 10, 2015).

Chubik, P., et al. (2013). Strategic Programme of National Research Tomsk Polytechnic University Competitiveness Enhancement in the Group of Top Level World Research and Academic Institutions. pp. 4-30.

Council of Europe (2001). Common European Framework of Reference for Languages: Learning, Teaching, Assessment. Cambridge: Cambridge University Press.

Development Priorities in Science, Technology and Engineering in the Russian Federation Have Been Approved // President of Russia. [Online] Available: http://eng.kremlin.ru/news/2530 (March 8, 2015).

Educational Standard // National Research Tomsk Polytechnic University. [Online] Available: http:/ttpu.ru/en/about/figures/bestpractices/education/es/ (March 5, 2015).

The Order of the Russian Federation Government of October 4, 2000, № 751. [Online] Available: http://elementy.ru/library9/doctrina.htm (March 10, 2015). 